\title{
Comparison between tests for tuberculosis diagnosis in slaughtered bovines
}

\section{Comparação entre testes de diagnóstico para tuberculose em bovinos abatidos}

\author{
David Attuy Vey da Silva1*, Márcio Junio Lima Siconelli², Karina Paes Bürger ${ }^{3}$, Lara Borges Keid ${ }^{1}$ \\ | | | | | | | | | | | | | | | | | | | | | | | | | | | | | | | | | | | | | | | | | | | | | | | | | | | | | | | | | | | | | | | | | | | | | | | | | | | | | | | | | | | | | | | | | | | | | | | | | | | | | | | | | | | | | | | | | | | | | | | | | | | | | | | | | | | | | | | | | | | | | | | | | | | | | | | | | | | | | | | | | | | | | | | | | | | | | | | | | | | | | | | | | | | | | | | | | | | | | |
}

\begin{abstract}
Our goal for this article is to compare several different diagnosis tests for bovine tuberculosis identification. We have performed bacterial isolation, histopathological characterization, acid-fast bacilli (AFB) identification and $M$. bovis DNA detection. Lesions suggestive of Tuberculosis were sampled from bovine lymph nodes during slaughtering of bovines at an abattoir that operates under federal inspection. The bacterial isolation was performed in solid culture mediums, the histopathological characterization was made by Hematoxylin-eosinstaining, and AFB identification by Ziehl-Neelsen staining. Bacterial DNA detection was performed by Polymerase Chain Reaction (PCR) using DNA from two different sources, directly collected from the tuberculosis-like lesions (PCR followed by nested PCR) and from isolated bacteria. We have concluded that the multi-step approach, including histopathological characterization, bacterial isolation and AFB identification, is strongly recommended to diagnose tuberculosis in bovines. Furthermore, PCR assays using specimens of lesions suggestive of tuberculosis are a faster and more promising way to diagnose the disease. However, it should not be used alone due to the low sensitivity shown in this study.
\end{abstract}

KEYWORDS: infectious diseases; Mycobacterium bovis; tuberculosis; zoonosis.
RESUMO: O objetivo deste estudo foi a comparaçáo entre diferentes testes de diagnóstico para tuberculose bovina. Foram realizados o isolamento bacteriano, a caracterização histopatológica, a identificação de bacilos álcool-ácido resistentes e a detecção do DNA de $M$. bovis pela reação em cadeia da polimerase, em bovinos adultos abatidos em matadouros frigoríficos sob o Serviço de Inspeçâo Federal, valendo-se de amostras de linfonodos com lesóes macroscópicas sugestivas de tuberculose, identificadas e coletadas durante o abate. $\mathrm{O}$ isolamento bacteriano foi realizado pelo cultivo em meios de cultura sólidos; a caracterização histopatológica, pela coloração com hematoxilina-eosina; e a identificação de bacilos álcool-ácido resistentes foi feita pela coloração de Ziehl-Neelsen. A detecção de DNA foi realizada em amostra extraída das lesóes sugestivas de tuberculose pela reação em cadeia da polimerase, seguida da nested reaçáo em cadeia da polimerase e por meio das colônias isoladas para identificação do M. bovis, utilizando-se também da reação em cadeia da polimerase. Os resultados obtidos permitiram concluir que os testes histopatológicos, o isolamento bacteriano e a identificaçáo de bacilos álcool-ácido resistentes são aconselháveis para o diagnóstico da tuberculose bovina. Além disso, ensaios de reação em cadeia da polimerase utilizando amostras de lesóes sugestivas de tuberculose são um modo mais rápido e promissor para diagnosticar a enfermidade, no entanto náo deve ser utilizado sozinho, em virtude da baixa sensibilidade apresentada neste estudo.

PALAVRAS-CHAVE: doenças infecciosas; Mycobacterium bovis; tuberculose; zoonose. 


\section{INTRODUCTION}

Tuberculosis is one of the main causes of death worldwide, affecting a variety of species. Mycobacteria from the Mycobacterium tuberculosis complex are known as the tuberculosis causative agent (COSTA et al., 2013). The occurrence of nodular granulomatous lesions are typical of this infirmity (FURLANETTO et al., 2012). Despite being found in almost all tissues of infected animals, the lesions are more frequently observed in lymph nodes, the lungs and the liver (CARDOSO et al., 2009; ROXO, 1997).

Post-mortem sanitary inspection has a great importance for tuberculosis epidemiological surveillance programs in countries where the disease is considered endemic, since it can considerably reduce its prevalence when allied to eradication programs (DE LA RUA-DOMENECH, 2006). PINTO (2003) states that among the foodborne zoonoses detected in the sanitary inspection, tuberculosis has the largest impact in economy and public health.

In addition to the post mortem sanitary inspection, the Mycobacterium spp. isolation, known as the gold-standard test for diagnosis, is a useful tool to diagnose tuberculosis, allowing the accurate identification of the mycobacteria. The main disadvantages of bacterial isolation are that it is a time-consuming method. It took 24 to 40 days until colonies become macroscopically visible. Moreover, dealing with live mycobacteria requires adequate sample handling (KONEMAN et al., 2001).

There are other complementary tests such as histopathological analysis by Hematoxylin-eosin staining and acid fast bacilli (AFB) identification using Ziehl-Neelsen staining (BRAZIL, 2008). Hematoxylin-Eosin staining allows the identification of granulomas, which are microscopic tuberculosis-like changes. The Ziehl-Neelsen staining focus on identifying the presence of AFB (BRAZIL, 2008).

PINTO et al. (2002) proved the importance of bacterial isolation allied with other tests to diagnose bovine tuberculosis, contributing with veterinarians' choices. ALZAMORA FILHO et al. (2014) demonstrated the need of anatomopathological identification associated with microbiological and molecular diagnosis to foment the epidemiological investigation of bovine tuberculosis by health surveillance agencies to control its incidence.

The PCR analysis is a viable option for a faster Detection of Mycobacterium spp. in clinical samples. This type of molecular detection on tissue samples had been broadly used to diagnose tuberculosis in some countries (FURLANETTO et al., 2012; TAYLOR et al., 2001; 2007), although in developing countries such as Brazil, it is not well known yet and as such might not cause much impact (ARAÚJO et al., 2014).

The increased interest in molecular diagnostic methods stems from difficulties faced to diagnose the disease in animals, mostly because of several limitations related to sensitivity and specificity of the tuberculin test and the time consumed with bacterial isolation (RORING et al., 2000). FURLANETTO et al. (2012) found five times more positive results in tuberculosis-like lesions than in bacterial isolation when PCR was the diagnostic method. The same authors emphasized that a multi-step approach to diagnose tuberculosis, with DNA detection and post-mortem inspection, could make surveillance actions easier and contribute with the success of the Brazilian National Program of Bovine Tuberculosis Control and Eradication. TAYLOR et al. (2007) also compared bacteriological tests with molecular assay to detect tuberculosis and highlighted the necessity to use both tests in association for a reliable diagnosis.

Therefore, this article has focused on identifying tuberculosis-like lesions from an abattoir under federal inspection, classify them and compare the results of different diagnostic methods aiming to improve reliability of bovine tuberculosis identification.

\section{MATERIALS AND METHODS}

\section{Anatomopathological analysis and sample characterization}

Fifty lymph nodes with tuberculosis-like lesions were sampled according to the Manual of Tuberculosis Bacteriology (BRAZIL, 1994), during the slaughter inspection procedures in slaughterhouses under federal inspection. The samples were collected, classified, identified, and stored in duplicate. Afterwards, half of the samples were frozen in order to perform bacteria isolation and DNA detection, the other half were kept in $10 \%$ formalin solution, in a volume proportion of 1:10 (sample/solution) and stored at room temperature for further histopathological diagnosis.

\section{Bacteria isolation}

We have followed a modified protocol previously described by FRANCO et al. (2013). The samples were thawed, and then macerated in a laminar flow cabinet. Approximately $1 \mathrm{~g}$ of the macerated material was placed inside $10 \mathrm{~mL}$ assay tubes added by $2 \mathrm{~mL}$ of physiological solution. Decontamination was done by Petroff technique (BALIAN et al., 2002). The Stonebrink-Leslie and Lowenstein-Jensen were the selective mediums used.

The bacterial culture was prepared in bottles for cell culture containing Stonebrink-Leslie or Lowenstein-Jensen mediums. For that, we used a sterile bacterial loop, then the bottles were incubated at $37^{\circ} \mathrm{C}$ until the multiplication of mycobacteria could be observed. Afterwards, the bottles were stored at room temperature. 


\section{Histopathological diagnosis}

The presumptive (by Hematoxylin-eosin staining) and confirmatory histopathological diagnosis (AFB identification by Ziehl-Neelsen staining) were done by fixating the samples in paraffin. Afterwards, fragments of $5 \mu \mathrm{m}$ of width were cut and used to prepare blade slides that were then analyzed with an optical microscope (BEHMER et al., 1976).

\section{M. bovis DNA detection by PCR}

\section{DNA extraction}

DNA was extracted from lesions and AFB colonies were prepared at the Laboratory of Molecular Epidemiology of FCAV/ UNESP/Jaboticabal/SP, using a modified chemical extraction protocol previously described by KURAMAE-IZIOKA (1997), in order to achieve the best possible quality and integrity of bacterial DNA.

The quality of DNA was evaluated by relative absorbance spectra of each sample using wave lengths of $260 \mathrm{~nm}$ and $280 \mathrm{~nm}$, adopting values between 1.8 and 2.0 as a desirable value (SAMBROOK; RUSSELL, 2001), with a NanoDrop-1000 (Thermo Scientific) spectrophotometer. In order to check DNA integrity, agarose gel electrophoresis ( $1 \%$ weight:volume proportion) was performed and then visually analyzed.

\section{PCR of the DNA extracted from the tuberculosis-like lesions}

A pair of SCAR (Sequenced Characterized Amplified Region Marker) to detect the presence of $M$. bovis in tissue samples has been chosen. Markers selected were JB21 (5' TCGTCCGCTGATGCAAGTGC 3') and JB22 (5' CGTCCGCTGACCTCAAGAAG 3'), to amplify a specific 500 bp region (RODRIGUEZ et al. 1999).

For PCR, we used a buffer containing $2 \mathrm{mM}$ de $\mathrm{MgCl}_{2}$, $0.2 \mathrm{mM}$ of dNTP's, $1 \mathrm{U}$ of Taq DNA polymerase, $5 \mathrm{pmol}$ of each SCAR marker, $1,2 \mu \mathrm{L}$ of total genomic DNA and $20 \mu \mathrm{L}$ of pure sterile water q.s.. A Veriti ${ }^{\circledast}$ thermocycler was operated as per the program: one cycle at $95^{\circ} \mathrm{C}$ for 3 minutes, 45 cycles at $94^{\circ} \mathrm{C}$ for 60 seconds, $60^{\circ} \mathrm{C}$ for 40 seconds and $72^{\circ} \mathrm{C}$ for 1 minute, finishing with one cycle of 10 minutes at $72^{\circ} \mathrm{C}$. The PCR product was subjected to $1 \%$ agarose gel (w:v) electrophoresis, stained with ethidium bromide $(0.5 \mu \mathrm{g} /$ $\mathrm{mL}$ ), with a $1 \mathrm{~kb}$ Plus DNA Ladder ${ }^{\otimes}$ as standard molecular size. The gel was read under UV light inside the photo-documentation equipment GEL DOC XR ${ }^{\circledR}$.
Because the samples are paucibacillary (previously known), a modification was applied to PCR to increase the sensitivity of bacterial DNA detection. The procedure is called Nested PCR and is commonly used with samples where bacterial DNA is found in low quantity (REBOLLO et al., 2006). The same PCR protocol was applied to Nested PCR analysis; however, the PCR product was added, rather than the DNA extracted from esions suggestive of tuberculosis.

\section{M. bovis DNA detection from bacterial colonies}

To assure presence of M. bovis in AFB colonies, the same pair of SCAR markers used in PCR from the tuberculosis-like lesions were used. The concentration and quantities of reagents were the same as well. The reaction was performed in a Veriti ${ }^{\oplus}$ thermocycler programmed for one cycle at $94^{\circ} \mathrm{C}$ for 5 minutes, 40 cycles at $94^{\circ} \mathrm{C}$ for $1 \mathrm{~min}$ ute, $68^{\circ} \mathrm{C}$ for 1 minute and $72^{\circ} \mathrm{C}$ for 1 minute and, finally, one cycle of 10 minutes at $72^{\circ} \mathrm{C}$. The PCR product was subjected to $1 \%$ agarose gel (w:v) electrophoresis, stained with ethidium bromide $(0.5 \mu \mathrm{g} / \mathrm{mL})$, with $1 \mathrm{~kb}$ Plus DNA Ladder $^{\circledR}$ as standard molecular size. The gel was also read under UV light inside the equipment of photo-documentation GEL DOC XR ${ }^{\circledast}$.

\section{Data analysis}

The database and the tables were assembled in the 2007 version of Microsoft Excel. Sensitivity, specificity and confidence intervals (CI) were calculated according to Thrusfield's method (2004). The agreement between results was calculated by the kappa coefficient (TAYLOR, 1992) and results were interpreted according to LANDIS; KOCH (1977). The mycobiological culture was considered the gold-standard test (true positive test). All calculations were made with the EpiR tool, in the statistical software R.

\section{RESULTS}

All the sampled tuberculosis-like lesions were classified as caseous (50/50), all of which had been collected from lymph nodes of various locations (Table 1), 50\% from the retropharyngeal lymph node, the most affected one, followed by mediastinal, pre-scapular, pre-pectoral, tracheobronchial, atloidian, sciatic, inguinal and hepatic lymph nodes.

Table 1. Lymph nodes of slaughtered cattle presenting tuberculosis-like lesions, from an abattoir under federal inspection.

\begin{tabular}{lccccccccc} 
Lymph nodes & $\mathbf{R L}^{\mathrm{a}}$ & $\mathbf{M L}$ & $\mathbf{P L}$ & $\mathbf{P P L}$ & $\mathbf{T L}^{\mathrm{e}}$ & $\mathbf{A F}^{\mathbf{f}}$ & $\mathbf{S L}^{\mathrm{g}}$ & $\mathbf{I N L}^{\mathrm{h}}$ & $\mathbf{H L}^{\mathbf{i}}$ \\
Positive Samples & $25 / 50$ & $11 / 50$ & $4 / 50$ & $3 / 50$ & $2 / 50$ & $1 / 50$ & $1 / 50$ & $1 / 50$ & $1 / 50$ \\
& $50 \%$ & $22 \%$ & $8 \%$ & $6 \%$ & $4 \%$ & $2 \%$ & $2 \%$ & $2 \%$ & $2 \%$ \\
\hline
\end{tabular}

${ }^{\mathrm{a}}$ Retropharyngeal lymph node, ${ }^{\mathrm{b}}$ Mediastinal lymph node, ${ }^{\mathrm{C}}$ Pre-scapular lymph node, ${ }^{\mathrm{d}}$ Pre-pectoral lymph node, ${ }^{\mathrm{e}}$ Tracheobronquial lymph node, ${ }^{f}$ Atloidian lymph node, ${ }^{9}$ Sciatic lymph node, 'Inguinal lymph node, 'Hepatic lymph node. 
There was no bacterial growth in Lowenstein-Jensen medium, while $56 \%(28 / 50)$ of the samples cultured in Stonebrink-Leslie medium showed bacterial growth typical of M. bovis (Fig. 1), suggesting that $100 \%$ of them were M. bovis.

Among histopathological slides, when stained by Hematoxylin-eosin (Fig. 2A), 64\% were positive, as microscopical tuberculosis-like lesions had been detected. When stained by Ziehl-Neelsen (Fig. 2B), AFB could not be identified in only $12 \%$ of the samples, which tested positive for Hematoxylineosin staining (Table 2).

The quality and integrity of bacterial DNA was desirable in the 50 tissue samples and in the $28 \mathrm{M}$. bovis isolates. The amplification conditions were checked previously and a $500 \mathrm{bp}$ PCR product indicates the presence of $M$. bovis. Bands with the same molecular size were amplified from a $M$. bovis reference strain (IB2-M. bovis AN5). Out of 50 tissue samples subjected to PCR, only $20 \%$ (10/50) were positive (Fig. 3) and out of 28 isolates, $100 \%$ (28/28) had M. bovis DNA detected.

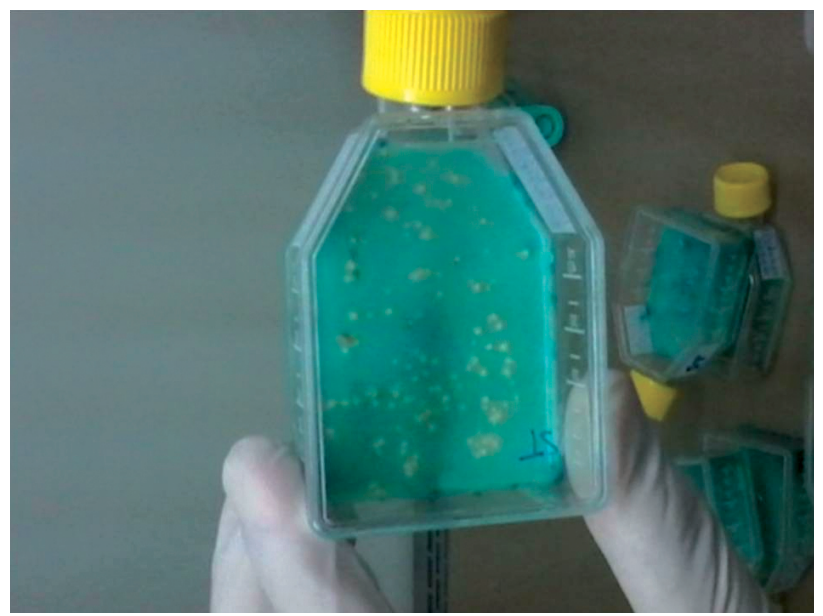

Figure 1. Sample 1ITVLRBM presenting typical growth of $M$. bovis colonies in solid. Stonebrink-Leslie medium, example of the gold-standard diagnostic test for tuberculosis.

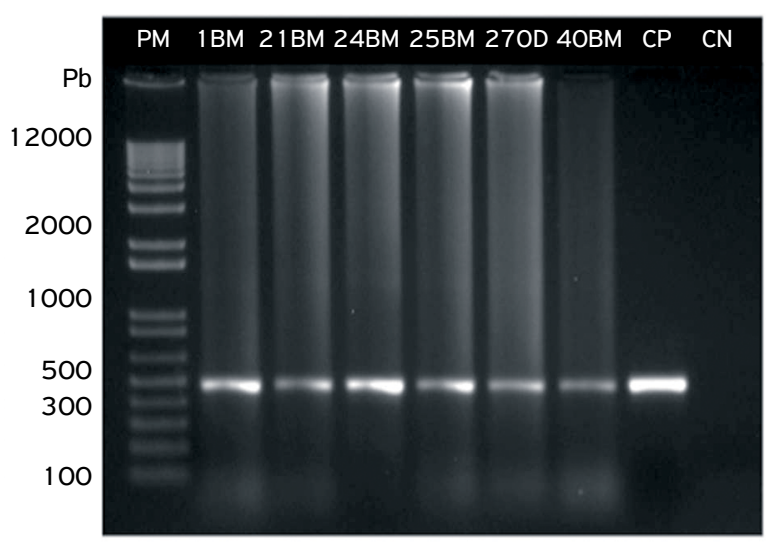

Figure 2. Agarose gel showing bands corresponding to M. bovis. The amplification was performed using DNA extracted from tuberculosis-like lesions. PM: molecular size pattern $1 \mathrm{~kb}$ Plus DNA Ladder (Invitrogen). CP: positive control. CN: negative control.
The strongest agreement between tests was bacterial culture and DNA detection, followed by histopathological diagnosis by Hematoxylin-eosin staining, AFB identification by Ziehl-Neelsen staining and DNA detection (PCR and nested PCR) from the tuberculosis-like lesions.

The best association between sensitivity and specificity, shown by the Youden index, was found in the DNA detection of isolates. Histopathological Hematoxylin-eosin staining, AFB identification by Ziehl-Neelsen staining and the DNA detection (PCR and nested PCR) in tuberculosis-like lesions had lower values.

\section{DISCUSSION}

Most of the affected lymph nodes were found in animals' head region. The same was reported by JORGE (2010) and by REZENDE-LAGO et al. (2011), who found the highest quantities of tuberculosis-like lesions in the head and thorax, allowing them to infer that the animals got the infection by breath. ALZAMORA-FILHO et al. (2014) analyzed 180 bovine carcasses and classified $100 \%$ of lesions as caseous. However, SILVA et al. (2014) observed 100 bovine carcasses

Table 2. Histopathological diagnosis of lymph nodes with tuberculosis-like lesions from cattle slaughtered in an abattoir under federal inspection.

\begin{tabular}{|cccc}
\hline \multicolumn{3}{c}{ Staining } \\
\multicolumn{3}{|c}{ Hematoxylin-Eosin } & \multicolumn{2}{c|}{ Ziehl-Neelsen } \\
\hline Positive & Negative & Positive & Negative \\
\hline $64.0 \%$ & $36.0 \%$ & $52.0 \%$ & $48 \%$ \\
$(32 / 50)$ & $(18 / 50)$ & $(26 / 50)$ & $(24 / 50)$ \\
\hline
\end{tabular}

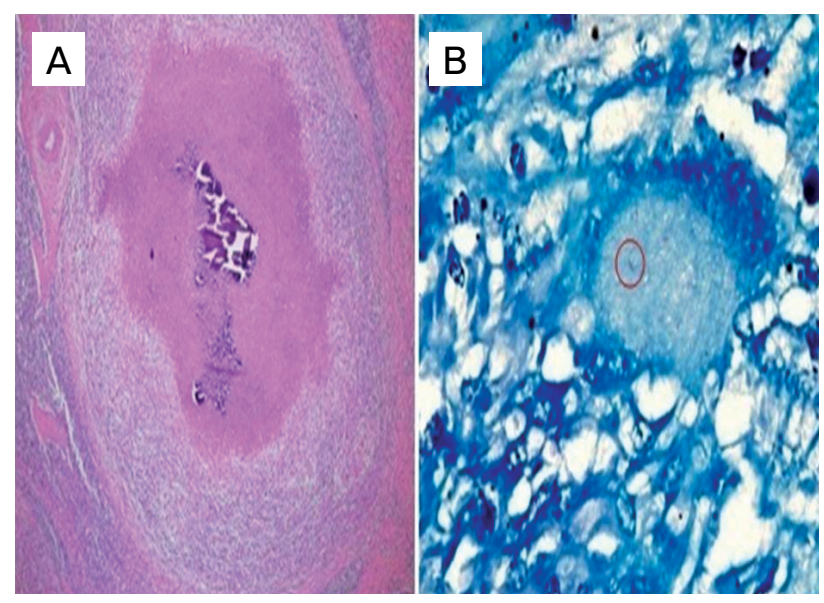

Figure 3. (A) Typical tuberculosis granuloma with central area of dystrophic calcification, necrosis, surrounded by inflammatory infiltrate composed mainly of macrophages. HE staining, 4-fold increase. (B) Histological section showing AFB (circled) inside the cytoplasm of a Langerhans type cell. ZN staining, 100-fold increase. 
with tuberculosis-like injuries and classified $85 \%$ of them as caseous and $15 \%$ as calcified. Despite the chronic course of tuberculosis, these data allow us to infer that the animals were slaughtered during the recent course of infection due to the type of lesions found (mostly caseous). The high occurrence of acute tuberculosis infections in slaughtered cattle shows that the disease is present in Brazilian herds e therefore poses threats to humans, who can consume meat and milk from infected animals. Furthermore, infected bovines are an infection source to those who work in food production industry, exposing them to the etiological agent while handling infected animals or products from infected animals. Therefore, tuberculosis can be considered a high-risk foodborne disease.

Despite all lesions having characteristics of tuberculosis lesions, the bacterial isolation was not possible in all of them due to some restrictions such as: low quantity of AFB in samples or even difficulties related to the high level of natural contamination. However, M. bovis isolation is the gold standard method for tuberculosis diagnosis, with specificity close to $100 \%$ (FRÁGUAS et al., 2008).

SA'IDU et al. (2015) reported $29.16 \%$ of positivity using tissue samples from 120 bovines with tuberculosis-like lesions. VARELLO et al. (2008) analyzed 173 suspected tissue samples from bovines and identified 117 of them (67.63\%) as tuberculosis using Hematoxylin-eosin staining, but when Ziehl-Neelsen staining was used, AFB was identified in only 31 samples (17.91\%). This data underlines the need to associate histopathological characterization and AFB identification, since the latter can be limited due to low quantity of bacteria in lesions.

Bacterial DNA detection was possible in 7\% (14/198) of tissue samples (FURNALETTO et al., 2012) and 5.9\% (2/34) of nasal swabs samples (FIGUEIREDO et al., 2010). However, CARDOSO et al. (2009) reported different data; the authors detected M. bovis DNA in 54.5\% (18/33) of all samples. These authors reported that the DNA concentration could interfere in PCR sensitivity, since they found 15\% more positive results after doubling or triplicating the DNA concentration in PCR analysis. The same was found in our study: $100 \%$ of our samples had M. bovis DNA detected when extracted from isolates.

AYELE et al. (2004) emphasize the need to standardize PCR when DNA from tuberculosis-like lesions is used, since the presence of natural inhibitors such as metal ions or contaminating microorganisms are considered critical and could alter the results of PCR analysis. The standardization would be helpful in PCR analysis in clinical samples, which usually present low quantities of bacteria. The process enables a faster and more reliable diagnosis, helping in actions aimed at public health and animal health surveillance.

The samples in which $M$. bovis DNA was not detected were then submitted to nested PCR analysis, which increased the number of positive samples increased from $20 \%$ (10/50) to
$38 \%(19 / 50)$. This was actually expected, because the reamplification of initial PCR products prevents false negative results. Other researchers who made similar use of nested PCR analysis reported similar (COSTA et al., 2013) or even higher increase in detection of positive samples (ARAÚJO et al., 2014).

Only $12 \%(6 / 50)$ of the samples were positive in all diagnosis tests used in this study. M. bovis DNA from tuberculosis-like lesions was less detected (19/50) by PCR than by other tests, such as bacterial isolation (28/50), histopathological characterization in Hematoxylin-eosinstained slides (32/50) and AFB identification by Ziehl-Neelsen staining $(26 / 50)$. That is why a multi-step approach involving microbiological and genetic tests requires a reliable method of $M$. bovis detection.

The perfect agreement between the tests was observed only between bacterial isolation, the gold standard test for bovine tuberculosis diagnosis, and $M$. bovis DNA detection in isolates by PCR (Table 3). This result was also expected, because $M$. bovis DNA detection in isolates is a genetic confirmation of the isolated bacteria. A slight agreement was found when bacterial isolation was compared to DNA detected from tuberculosis-like lesions by PCR. Fair concordance was seen when DNA detection by nested PCR and bacterial isolation were compared. Comparisons between histopathological tests resulted in slight agreement as well. LIMA et al. (2008) reported better agreement results when comparing bacterial isolation and DNA detection by PCR in human sputum samples collected from patients with suspected tuberculosis, which makes possible to infer that the molecular identification of Mycobacterium spp. is a viable alternative for diagnosis.

The histopathological characterization with Hematoxylineosinstained slides showed substantial agreement with AFB identification by Ziehl-Neelsen staining, while there was a moderate/fair concordance compared with bacterial isolation; FRÁGUAS et al. (2008) reported the same results. It is noticeable that AFB identification by Ziehl-Neelsen staining had similar agreement with DNA detection in tuberculosis-like lesions by PCR when both were compared to bacterial isolation. Therefore, AFB identification is the most feasible alternative to diagnose tuberculosis.

FURLANETTO et al. (2012) and FIGUEIREDO et al. (2010) had more satisfying results when comparing DNA detection in tuberculosis-like lesions and bacterial isolation. However, the molecular identification was less successful when nasal swab samples were used $5.9 \%$ of positive animals), as bacterial isolation also showed poor results (no bacterial growth); but when samples from bovine's lymph nodes and lungs were tested, $50 \%$ of them were positive. Analyzing such results altogether, one can notice that it is important to keep the bacterial isolation as gold standard test for bovine tuberculosis diagnosis, especially when used in association with DNA detection in isolates by PCR, in order to confirm the etiological agent. The values of sensitivity, specificity 
and Youden's coefficient of the diagnostic tests analyzed in this study (Table 4) are in agreement with the concordance test, since the best concordances were shown between DNA detection of the isolates by PCR, followed for the histopathological diagnosis and the detection of bacterial DNA in the lesions suggestive of tuberculosis by PCR, when compared to the microbiological isolation (gold standard, considered true positive for sensitivity and specificity tests).

The Youden coefficient was used to identify which test hadthe smallest proportion of false diagnoses (the smallest amount of wrong diagnoses, false negative plus false positives). The best coefficient values were found for DNA detection by PCR, followed by histopathological diagnosis using Hematoxylin-eosinstained slides, AFB identification by Ziehl-Neelsen staining, the lowest coefficient being that of DNA detection from bovine tuberculosis-like lesions by PCR.

Important to highlight that the type of sample used to diagnose tuberculosis is of utter importance once the results are directly influenced by the quantity of bacilli present in the sample collected. The low sensitivity values shown in this study for DNA detection by PCR from tuberculosis-like lesions (from 25.00 to $33.33 \%$ ) were due to the low quantity of bacilli in the samples, mainly when compared to bacterial isolation. Therefore, when molecular tests are applied in tuberculosis-like lesions, high percentages of false negative results could be found, impairing the quality of results.

\section{CONCLUSIONS}

We have concluded that histopathological tests, bacterial isolation and AFB identification in bovine samples are advisable for the diagnosis of bovine tuberculosis. DNA detection from tuberculosis-like lesions by PCR is a faster and promising method to diagnose bovine tuberculosis, however a multi-step approach involving culturing and identification of bacteria is required, as well as its histopathological characterization and molecular analysis, so one can have a reliable method to diagnose bovine tuberculosis.

Table 3. Agreement between diagnostic tests expressed by the Kappa coefficient.

\begin{tabular}{|c|c|c|}
\hline Diagnostic tests & Kappa Coefficient $(95 \% \mathrm{Cl})$ & Agreement \\
\hline Microbiological $x$ hematoxylin-eosin & $0.420(0.147$ a 0.694$)$ & Moderate \\
\hline Microbiological x Ziehl-Neelsen & $0.357(0.081$ a 0.633$)$ & Fair \\
\hline Microb. x PCR - Lesions & $0.104(-0.101$ a 0.310$)$ & Slight \\
\hline Microb. x Nested PCR & $0.221(-0.030$ a 0.473$)$ & Fair \\
\hline Microb. x PCR - Colonies & $1.000(0.723$ a 1.278$)$ & Almost Perfect \\
\hline Hematoxylin-eosin x Ziehl-Neelsen & $0.757(0.488$ a 1.026$)$ & Substantial \\
\hline Hematoxylin-eosin x PCR - Lesions & $0.110(-0.073$ a 0.292$)$ & Slight \\
\hline Hematoxylin-eosin x Nested PCR & $0.023(0.006$ a 0.463$)$ & Slight \\
\hline Hematoxylin-eosin x PCR - Colonies & $0.421(0.147$ a 0.694$)$ & Moderate \\
\hline Ziehl-Neelsen x PCR - Lesions & $0.141(-0.076$ a 0.357$)$ & Slight \\
\hline Ziehl-Neelsen x Nested PCR & $0.280(0.014$ a 0.546$)$ & Fair \\
\hline Ziehl-Neelsen x PCR - Colonies & $0.357(0.081$ a 0.633$)$ & Fair \\
\hline PCR - Lesions x Nested PCR & $0.000(-2.052$ a 2.052$)$ & Slight \\
\hline PCR - Lesions x PCR - Colonies & $0.104(-0.101$ a 0.310$)$ & Slight \\
\hline Nested PCR x PCR - Colonies & $0.221(-0.030$ a 0.473$)$ & Fair \\
\hline
\end{tabular}

95\% Cl: 95\% Confidence interval.

Table 4. Sensitivity, specificity and Youden coefficient of diagnostic tests analyzed versus bacterial isolation.

\begin{tabular}{lcccc} 
Diagnostic tests & Sensitivity (\%) & Specificity (\%) & $\begin{array}{c}\text { Sensitivity + } \\
\text { specificity }\end{array}$ & $\begin{array}{c}\text { Youden coefficient } \\
(\%)\end{array}$ \\
\hline Hematoxylin-eosin & 82.14 & 59.09 & 141.23 & 41.23 \\
\hline Ziehl-Neelsen & 67.86 & 68.18 & 136.04 & 36.04 \\
\hline PCR - Lesions & 25.00 & 86.36 & 111.36 & 11.36 \\
\hline Nested PCR & 33.33 & 89.47 & 122.80 & 22.80 \\
\hline PCR - Colonies & 100.00 & 100.00 & 200.00 & 100.00 \\
\hline
\end{tabular}



REFERENCES

ALZAMORA-FILHO, F.; VASCONCELLOS, S.E.G.; GOMES, H.M.; CAVALCANTE, M.P.; SUFFYS, P.N.; COSTA, J.N. Múltiplas estirpes de isolados de Mycobacterium bovis identificados por tipagem molecular em bovinos abatidos em matadouros-frigoríficos. Pesquisa Veterinária Brasileira, v.34, n.2, p.103-108, 2014.

ARAÚJO, C.P.; OSÓRIO, A.L.R.; JORGE, K.S.G.; RAMOS, C.A.N.; SILVA FILHO, A.F.; VIDAL, C.E.S.; ROXO, E.; NISHIBE, C.; ALMEIDA, N.F.; FONSECA JÚNIOR, A.A.; SILVA, M.R.; BARBOSA NETO, J.D.; CERQUEIRA, V.D.; ZUMÁRRAGA, M.J.; ARAÚJO, F.R. Detection of Mycobacterium bovis in bovine and bubaline tissues using Nested-PCR for TBD 1. PLoS One, v.9, n.3, 2014. https://doi. org/10.1371/journal.pone.0091023

AYELE, W.Y.; NEILL, S.D.; ZINSSTAG, J.; WEISS, M.G.; PAVLIK, I. Bovine tuberculosis: an old disease but a new threat to Africa. The International Journal of Tuberculosis and Lung Diseases, v.8, n.8, p.924-937, 2004.

BALIAN, S.C.; PINHEIRO, S.R.; GUERRA, J.L.; MORAIS, Z.M.; FERREIRA, F.; FERREIRA NETO, J.S. Estudo comparativo de dois métodos de descontaminação na pesquisa de micobactérias. Arquivos do Instituto Biológico, v.69, n.2, p.11-14, 2002.

BEHMER, O.A.; TOLOSA, E.M.C.; FREITAS NETO, A.G. Manual de técnicas para histologia normal e patológica. São Paulo: EDART, Editora da Universidade de São Paulo, 241p, 1976.

CARDOSO, M.A.; CARDOSO, R.F.; HIRATA, R.D.C.; HIRATA M.H.; LEITE, C.Q.F.; SANTOS, A.C.B.; SIQUEIRA, V.L.D.; OKANO, W.; ROCHA, N.S.; LONARDONI, M.V.C. Direct Detection of Mycobacterium bovis in bovine lymph nodes by PCR. Zoonoses Public Health, v.56, p.465-470, 2009. https://doi. org/10.1111/j.1863-2378.2008.01199.x

COSTA, P.; FERREIRA, A.S.; AMARO, A.; ALBUQUERQUE, T.; BOTELHO, A.; COUTO, I.; CUNHA, M.V.; VIVEIROS, M.; INÁCIO, $J$. Enhanced detection of tuberculous mycobacteria in animal tissues using a Semi-Nested Probe-Based Real-Time PCR. PLoS One, v.8, n. 1 1, e81337, 2013. https://doi.org/10.1371/journal. pone.0081337

DE LA RUA-DOMENECH, R. Human Mycobacterium bovis infection in the United Kingdom: incidence, risks, control measures and review of the zoonotic aspects of bovine tuberculosis. Tuberculosis, v.86, p.77-109, 2006

FIGUEIREDO, E.E.S.; CARVALHO, R.C.T.; SILVESTRE, F.G. LILEMBAUM, W.; FONSECA, L.S.; SILVA, J.T.; PASCHOALIN, V.M.S. Detection of Mycobacterium bovis DNA in nasal swabs from tuberculous cattle by a multiplex PCR. Brazilian Journal of Microbiology, v.41, n.2, p.386-390, 2010. http://dx.doi. org/10.1590/S1517-83822010000200020

FRÁGUAS, S.A.; CUNHA-ABREU, M.S.; FERREIRA, A.M.R.; MARASSI C.D.; OELEMANN, W.; FONSECA L.S.; FERREIRA, R.; LILENBAUM, W. Estudo comparativo de métodos complementares para o diagnóstico da tuberculose bovina em animais reagentes à tuberculinização. Revista Brasileira de Ciência Veterinária, v. 15, n.3, p.117-121, 2008. https://doi.org/10.22409/rbcv.v15i3.383
FRANCO, M.M.G.; PAES, A.C.; RIBEIRO, M.G.; PANTOJA, J.C.F.; SANTOS, A.C.B.; MIYATA, M.; LEITE, C.Q.F.; MOTTA, R.G.; LISTONI, F.J.P. Occurrence of mycobacteria in bovine milk samples from both individual and collective bulk tanks at farms and informal markets in the southeast region of Sao Paulo, Brazil. BMC Veterinary Research, v.9, n.85, 2013. https://doi. org/10.1186/1746-6148-9-85

FURLANETTO, L.V.; FIGUEIREDO, E.E.S.; CONTE JÚNIOR, C.A.; CARVALHO, R.C.T.; SILVA, F.G.S.; SILVA, J.T.; LILENBAUM, W.; PASCHOALIN, V.M.S. Uso de métodos complementares na inspeção post mortem de carcaças com suspeita de tuberculose bovina. Pesquisa Veterinária Brasileira, v.32, n. 11 , p. $1138-1144,2012$. http://dx.doi.org/10.1590/ so100-736X2012001100011

JORGE, K.S.G. Identificação de Mycobacterium bovis em bovinos e sua importância na ocorrência de tuberculose zoonótica. Tese de Doutorado, Universidade Federal de Mato Grosso do Sul, Campo Grande-MS, 2010. 88p.

KONEMAN, E.W.; ALLEN, S.D.; JANDA, W.M.; SCHRECKENBERGER, P.C.; WINN JUNIOR, W.C. Diagnóstico Microbiológico: Texto e atlas colorido. Rio de Janeiro: Medsi, 2001. p. 903-946,

KURAMAE-IZIOKA, E.E. A rapid, easy and high yield protocol for total genomic DNA isolation of Colletotrichum gloesporioides and Fusarium oxysporum. Revista Unimar, v. 19, p.683-689, 1997.

LANDIS, R.J.; KOCH, G.G. The measurement of observer agreement for categorical data. Biometrics, v.33, p.159-174, 1977.

LIMA, S.S.S.; CLEMENTE, W.T.; PALACI, M.; ROSA, R.V.; ANTUNES, C.M.F.; SERUFO, J.C. Métodos convencionais e moleculares para o diagnóstico da tuberculose pulmonar: um estudo comparativo. Jornal Brasileiro de Pneumologia, v.34, n.12, p.1056-1062, 2008. http://dx.doi.org/10.1590/ S1806-37132008001200011

PINTO, P.S.A. Atualização em controle da tuberculose no contexto da inspeção de carnes. Bioscience Journal, v. 19, n.1, p. $115-121,2003$.

PINTO, P.S.A.; FARIA, J.E.; VILORIA, M.I.V.; BEVILACQUA, P.D. Exame microbiológico da tuberculose como subsídio à inspeção post-mortem de bovinos. Revista Brasileira de Saúde e Produção Animal, v.3, n.1, p.10-15, 2002. http://dx.doi. org/10.1590/1808-1657000592014

REBOLLO, M.J.; SAN JUAN GARRIDO, R.; FOLGUEIRA, D.; PALENQUE, E.; DÍAZ-PEDROCHE, C.; LUMBRERAS C. Blood and urine samples as useful sources for the direct detection of tuberculosis by polymerase chain reaction. Diagnostic Microbiology and Infectious Disease, v.56, n.2, p.141-146, 2006. http://dx.doi. org/10.1016/j.diagmicrobio.2006.03.018

REZENDE-LAGO, N.C.M.; REIS, L.S.; MARCHI, P.G.F. Levantamento epidemiológico da cisticercose e tuberculose em bovinos abatidos sob inspeção federal no município de Sertãozinho, SP. Revista Higiene Alimentar, v.25, n.192/193, p.175-181, 2011. 
RODRIGUEZ, J.G.; FISSANOTO, J.C.; PORTILLO, P.D.; PATARROYO, M.E.; ROMANO, M.I.; CATALDI, A. Amplification of a 500 base-pair fragment from cultured isolates of Mycobacterium bovis. Journal of Clinical Microbiology, v.37, n.7, p.23302332, 1999.

RORING, S.; HUGHES, M.S.; SKUCE, R.A.; NEILL, S.D. Simultaneous detection and strain differentiation of Mycobacterium bovis directly from bovine tissue specimens by spoligotyping. Veterinary Microbiology, v.74, n.3, p.227-236, 2000.

ROXO, E. Mycobacterium bovis como causa de zoonose. Revista Brasileira de Ciências Farmacêuticas, v.18, p.101-108, 1997.

SAMBROOK, J.; RUSSEL, D.W. Molecular cloning: a laboratory manual. 3ed. Londres: CSHL Press, 1448 p., 2001.

SILVA, D.A.V.; BÜRGER, K.P.; MARTINS, A.M.C.V.; PROVIDELLO, A. Identificação de lesões macroscópicas sugestivas de tuberculose bovina. Revista Brasileira de Higiene $e$ Sanidade Animal, v.8, n.2, p.149-160, 2014. http://dx.doi. org/10.5935/1981-2965.20140026
TAYLOR, G.M.; WORTH, D.R.; PALMER, S.; JAHANS, K.; HEWINSON, R.G. Rapid detection of Mycobacterium bovis DNA in cattle lymph nodes with visible lesions using PCR. B.M.C. Veterinary Research, v.3, n.12, 2007. http://dx.doi.org/10.1 186/1746-6148-3-12

TAYLOR, M.J.; HUGHES, M.S.; SKUCE, R.A.; NEILL, S.D. Detection of Mycobacterium bovis in bovine clinical specimens using real-time fluorescence and fluorescence resonance energy transfer probe rapid-cyclePCR. Jounal of Clinical Microbiology, v.39, n.4, p.1272-1278, 2001. http://dx.doi.org/10.1128/JCM.39.4.1272-1278.2001

TAYLOR, R.N. Measurement of variation and significance in serological test. [S.I.]: Academic Press, 1992. 29 p.

THRUSFIELD, M. Epidemiologia veterinária. 2 ed. São Paulo: Roca, 2004. 556 p.

VARELLO, K.; PEZZOLATO, M.; MASCARINO, D.; INGRAVALLE, F.; CARAMELLI, M.; BOZZETTA, E. Comparison of histologic techniques for the diagnosis of bovine tuberculosis in the framework of eradication programs. Journal of Veterinary Diagnostic Investigation, v.20, n.2, p.164-169, 2008. 